\title{
EUROPEAN RED CROSS YOUTH CONFERENCE
}

Over a hundred delegates took part in the first all-European Red Cross Youth Conference, organized by the Bulgarian Red Cross, in co-operation with the League of Red Cross Societies. Held at Varna, Bulgaria, from 9 to 20 July 1972, the Conference drew delegates from the National Societies of the following countries: Austria, Belgium, Bulgaria, Czechoslovakia, Denmark, Finland, France, German Democratic Republic, Federal Republic of Germany, Greece, Hungary, Italy, the Netherlands, Norway, Poland, Romania, Spain, Sweden, Turkey, United Kingdom, USSR and Yugoslavia. This was the first international Red Cross meeting in which Red Cross Youth members and National Directors, and leaders of National Societies, including Presidents, Vice-Presidents and Secretaries General, had sat together to discuss common problems. Representatives of the League, the ICRC and the HenryDunant Institute were also present.

The aims of the conference were:

- to discuss and suggest solutions to health and social problems which interest and affect young people in their countries;

- to discuss and suggest solutions to problems which young people have in working in Red Cross, particularly related to their participation in planning and decision-making at all levels in their National Societies;

- to discuss and suggest ways to recruit more young people to the Red Cross.

Youth Commissions of the Bulgarian Red Cross began working at least two years in advance preparing the conference. They had proposed two main themes, with sub-themes, for discussion, and these were submitted to all invited Societies for their comments. On the basis of their reactions, the final themes and sub-themes were selected: 


\section{IN THE Red Cross WORLD}

Theme I: Effects of technical and scientific progress on the health and welfare of young people in Europe

Sub-Themes: 1. Opportunities for participation of Red Cross Youth in programmes and activities for preventing the harmful effects of automation, urbanization and environmental pollution on health and life:

- ensuring healthy living and working environments;

- prevention of accidents on the roads, in schools, at home, and in industries;

- use of modern communications media for information on Red Cross Youth programmes and activities in this field.

2. Health education programmes and activities for young people:

- personal and environmental health;

- preparation for family life;

- smoking, alcohol and drugs;

- use of modern communications media for information on Red Cross Youth programmes and activities in this field.

3. Education and activities related to social problems:

- assistance to young families;

- helping disabled, aged and isolated people;

-w use of modern communications media for propaganda of Red Cross Youth programmes and activities in this field.

Theme II: Red Cross and contemporary youth-the role of young people in the organization

Sub-Themes: 1. New opportunities for more active participation of Red Cross Youth in the popularization of Red Cross activity. 
2. Problems of youth participation in Red Cross:

- participation in elective bodies, planning and decision-making of all Red Cross programmes at different levels (local, national and international);

- partnership of young people and adults in practical Red Cross activity;

- young people plan and organize their own programmes for various age groups;

- training of Red Cross Youth leaders.

3. Participation of young people in the promotion of peace and international co-operation:

- possibilities for strengthening mutual contacts among Red Cross Youth;

- joint programmes for practical co-operation among National Societies from different countries;

- training of youth groups for assisting the developing countries as well as for relief actions in case of disaster;

- extending mutual co-operation with other organizations working in the field of international co-operation and friendship among youth.

After the opening address delivered by Mr. Pierre Boissier, Director of the Henry-Dunant Institute, Theme I was introduced by Mr. Peter Kuenstler, Social Affairs Officer of the United Nations Office in Geneva. Analysing the situation of young people aged 18-25 in Europe today, Mr. Kuenstler selected a number of health and welfare problems to illustrate their special needs: accidents, suicide, venereal disease, the use of drugs. He described some of the threats to the human environment, and mentioned questions of responsible parenthood and family welfare. He then suggested some tasks that young Red Cross members could tackle, not only in seeking remedies for the problems, but also identifying their roots and causes and engaging in preventive measures, both of an educational and a social nature. 


\section{IN THE Red CRoss World}

Theme II was introduced by Yanko Mihailov, a student member of the Central Youth Committee of the Bulgarian Red Cross, who related this paper to the three sub-themes. He pointed out that it is particularly important for youth to involve themselves in spreading knowledge of the Red Cross, and went on to ask participants to produce concrete suggestions for effectively integrating young people in the planning and implementation of national and international Red Cross programmes. Finally, in speaking of the role and responsibility of Red Cross in the promotion of peace, Mr. Mihailov stated that it is this work which represents a true basis for co-operation and mutual understanding among countries and peoples.

Each theme and its sub-themes were discussed by participants in small working groups, which reported back to plenary sessions. At a plenary session on the last day the conference adopted a series of conclusions which National Societies were encouraged to study and implement. Among other things, these related to:

- Environment

- Accidents and accident prevention

- Assistance to young families

- Assistance to individuals and groups with physical, mental and social handicaps

- Participation of young people in Red Cross

- Consolidating peace and international co-operation

- Ensuring continuity in the development of Red Cross Youth programmes 